\title{
RELASI AGAMA DAN NEGARA DALAM GERAKAN KEAGAMAAN BARU: STUDI KASUS KOMUNITAS HERE KRISNA YOGYAKARTA
}

\author{
Budi Nurhamidin \\ Pascasarjana Universitas Islam Negeri Sunan Kalijaga Yogyakarta \\ budinurbamidin13@gmail.com \\ Arifin Kusuma Wardani \\ Pascasarjana Universitas Islam Negeri Sunan Kalijaga Yogyakarta \\ arifink.usumawardanidani@gmail.com
}

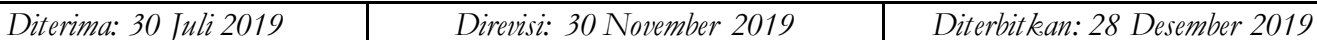

\begin{abstract}
This article aims to see and analyze the relationship between religion and the state towards the Here Krisna sect as a spiritual movement found in Hinduism. This study uses a qualitative method with a case study approach. The problem in this study is whether there is a religious politics that occurs in Hinduism and how the relationship between religion and the state. In this regard, the points that will be elaborated by researchers include the background of the emergence of Here Krisna, the teachings conveyed, the vision of transformation, religiouspolitics, and the relationship between religion and the state. This study results obtained that the emergence of the Here Krina stream does not become a problem for the Parisada Hindu Dharma Indonesia (PHDI) because its existence does not make people uneasy about Hindus in general, as well as the relationship between religion and state philosophically the first precepts that read the Almighty God is based as a philosophical basis for national life and state. From the results of this study, it can be understood that the Here Krisna stream can exist because it is based on Hinduism, which is an official religion and its social norms do not interfere with social life and its teachings do not conflict with the ideology of the nation as the basis of the state.
\end{abstract}

Keywords: Religious politic, New Religious Movement, Here Krisna.

\begin{abstract}
Abstrak
Artikel ini bertujuan untuk melihat dan menganalisa relasi antara agama dan negara terhadap kelompok aliran Here Krisna sebagai gerakan spiritual yang terdapat di agama Hindu. Studi ini mengunakan metode kualitatif dengan pendekatan studi kasus. Permasalahan dalam studi ini adalah apakah ada politik keagamaan yang terjadi di agama Hindu dan bagaiman relasi antara agama dan negara. Berkaitan dengan hal ini, poin yang akan dijabarkan oleh studi ini meliputi latar belakang kemunculan Here Krisna, pengajaran yang disampaikan, visi tranformasinya, politik keagamaan, serta relasi agama dengan negara. Adapun hasil studi yang didapat bahwasanya kemunculan aliran Here Krina tidak menjadi masalah bagi pihak Parisada Hindu Dharma Indonesia (PHDI) karena keberadaannya tidak membuat resah terhadap umat Hindu pada umumnya, serta relasi antara agama dan negara secara filosofis sila pertama yang berbunyi Ketuhanan Yang Maha Esa berkedudukan sebagai dasar filosofis bagi kehidupan berbangsa dan bernegara. Dari hasil studi ini dapat dipahami bahwasanya aliran Here Krisna bisa eksis karena bernaung di agama Hindu, yang merupakan agama resmi dan norma sosialnya tidak bersinggungan dengan kehidupan sosial dan ajarannya tidak bertentangan dengan ideologi bangsa sebagai dasar negara.
\end{abstract}

Kata Kunci: Politik keagamaan, Gerakan Keagamaan Baru, Here Krisna. 


\section{PENDAHULUAN}

Negara Indonesia merupakan negara yang memiliki corak kebudayaan yang multikultur, baik dari segi agama, suku, bahasa, dan budaya. Beberapa agama dunia dan agama lokal pun ikut berkembang, ini menandakan bahwasanya negara Indonesia merupakan negara yang sangat plural. Didalam mengatur keberagaman yang ada tentunya pemerintah harus mengeluarkan kebijakan salah satunya dengan membuat aturan tentang keagamaan.

Harus kita sadari bahwasanya sejak kemerdekaan negara Indonesia telah mengakui seperti yang tertulis dalam Undang-undang dasar 1945, dimana aturan ini mengikat negara untuk mendukung agama sebagai kayakinan masyarakatnya. Itu juga secara tidak langsung diakui dalam Pembukaan Konstitusi pancasila yang terdapat pada sila pertama yang berbunyi Ketuhanan yang Maha Esa. Bunyi dalam sila ini menggambarkan pluralitas para pendiri bangsa yang tidak mendirikan negara dengan salah satu keyakinan agama mayoritas, melainkan negara yang mampu mengayomi semua agama sebagai penghargaan terhadap para pejuang bangsa yang beragama non muslim dengan mengubah kata Allah dengan kata tuhan agar lebih umum pemaknaannya. ${ }^{1}$ Dengan mendasarkan kepada kebijakan pemerintah bisa dikatakan bahwa agama yang ada di Indonesia dibedakan menjadi dua kategori, yaitu, official religion atau agama yang memperoleh pengakuan dari pemerintah untuk hidup dan berkembang di Indonesia. Kedua, Noofficial religion yaitu agama yang tidak diakui oleh pemerintah tetapi dipandang sebagai aliran atau cabang dari agama yang diakui oleh pemerintah. ${ }^{2}$

Konsep negara hukum memberikan konsekuensi bagi negara Indonesia untuk mengatur segala kehidupan masyarakatnya untuk mencapai tatanan kehidupan yang tertib dan

1 Julia D. Howell, "Muslims, the New Age and Marginal Religions in Indonesia: Changing Meanings of Religious Pluralism", Jurnal Social Compas 52, no. 4 (2005): 474 .

2 Kotimah, "Agama dan Civil Society", Jurnal Ushuluddin XXI, no. 1 (Januari 2014): 123. memberikan kepastian hukum dalam hal ini berkaitan dengan keyakinan beragama seperti yang tertulis dalam Pasal 29 ayat (1) Undangundang Dasar 1945. ${ }^{3}$ Ketika kita pahami bahwasanya agama merupakan sesuatu yang menjembatani antara manusia dengan tuhannya tentu kita sebagai manusia harus menghargai keyakinan agama lain sebagai nilai moral dan pengakuan hati nurani masyarakat terhadap tuahan-Nya.

Dalam tema penting ini kita dapat membaca fenomena kehidupan agama di Indonesia yakni dengan adanya gerakan agama baru atau yang sering kita kenal dengan aliran sempalan dengan arus utama agama-agama tradisional yang telah mapan ditengah kehidupan masyarakat. Akibat dari pasca revormasi 1998 menjadikan gerakan agama baru ini berani muncul kepermukaan untuk menyebarkan paham dari aliran agamanya. Fenomena semacam ini tentunya perlu menjadi perhatian dari pemerintah ${ }^{4}$ agar tidak terjadi benturan antara agama yang sudah diakui di Indonesia (Islam, Kristen, katolik, Hindu, Budha, dan Konghuchu) dengan agama baru yang mengklain dirinya termasuk dalam salah satu agama yang sudah diakui namun dari segi pemahaman dan gerakannya sangat berbeda.

Letak kemunculan agama baru atau gerakan keagamaan yang di nilai menyimpang dari agama pada umumnya yang di sepakati oleh negara yaitu Islam, Hindu, Budha, Kristen Protestan, Kristen Katolik, dan Konghucu, sesungguhnya tidak terlepas dari adanya kesadaran kejiwaan manusia yang mencari titik kenyamanan, atau ada kepentingan politik yang lain karena pada zaman yang baru ini (new age) banyak individu yang mecari kenyamanan dan ketenangan melalui agama atau komunitas yang sebenarnya tidak di akui oleh negara dan ada juga indikasi

3 Hwian Christianto, "Arti Penting Uu No. 1/Pnps/1965 Bagi Kebebasan Beragama", Jurnal Yudisial 6, no. 1 (2013): 3 .

4 Mohammad Takdir, "New Spiritual Movement: Menelisik Visi Transpormatif Komunitas Lia Eden sebagai Embrio lahirnya New Age di Indonesia", Jurnal Theologia 12, no. 1 (Juni 2018): 2. 
penyimpangan dari agama resmi karena adanya indikasi politik dalam beragama. Fenomena ini tidak terlepas dari ruang kosong pemikiran manusia melainkan berdasarkan kenyataan bahwa manusia moderen telah kehilangan kesadaran untuk beragama yang sehat dan penuh kearifan. ${ }^{5}$

Pada intinya kemunculan agama baru sesungguhnya berakar dari krisis sepiritual dan moral yang di alami oleh kaum beragama, mereka mengangap agama yang di anut sudah tidak relevan lagi untuk di jalankan karena syariat yang di terapkan tidak memberikan efek kenyamanan, ketenangan dan keuntungan materil terhadap kehidupan yang di alaminya. Hal ini bisa terjadi karena kebanyakankan masyarakat memiliki pondasi agama yang tidak kuat atau sering di sebut imannya lemah pada keyakinan agama formal pada umumnya. Kemunculan gerakan keagamaan baru membuat kita bertanya tanya apakah agama formal sudah tidak relevan lagi untuk di yakini, tentunya faktor perubahan sosial masyarakat dan agama seperti radikalisme, fundamentalisme, sekularisme, dan perubahan sosial lainya yang berpengaruh pada cara pandang dan cara berfikir masyarakat moderen saat ini, bahkan kebanyakan masyarakat tidak mendengarkan nasehat para ulama, ustadz, pendeta, dalam mengajarkan agama formal seperti kajian-kajian yang di lakukan masing-masing agama pada umumnya.

Dari beberapa hasil kajian tentang aliran keagamaan penelitian ini tentunya berusaha ingin memberikan perbedaan gambaran dari penelitian sebelumnya yang lebih berfokus pada ajaran dan dampaknya terhadap kehidupan beragam, ${ }^{6}$ dinamika aliran agama sempalan, ${ }^{7}$ dan Hubungan

5 Mohammad Takdir, "New Spiritual Movement: Menelisik Visi Transpormatif Komunitas Lia Eden sebagai Embrio lahirnya New Age di Indonesia", 3.

6 Suhanah, "Kelompok Spritual Sakkhi dan Dampak Terhadap Kehidupan Keagamaan di Indonesia", Jurnal Multikultural dan Multireligius 15, no. 3 (2016): 3.

7 Abbas Langaji, "Dinamika Aliran Keagamaan Sempalan: Tinjauan Perspektif Sosiologi Agama”, Jurnal Hikmah XII, no. 1 (2016): 141. antara agama dan Negara. ${ }^{8}$ Fokus tulisan ini tentunya lebih melihat pada bagaiaman peran agama sempalan dalam relasi hubungan dengan negara agar tetap terus eksis dan tidak mendapatakn diskriminasi dari negara itu sendiri.

Dalam hal ini pembahasan tersebut di anggap penting, ketertarikan penulis terhadap gerakan Here Krisna yang berkembang di indonesia khususnya di Yogyakarta, ini memberikan dan menghadirkan sebuah warna dan dinamika baru dalam gerakan keagamaan di indonesia khususnya di Yogyakarta. Sebagai gerakan agama baru tentunya harus mendapatkan perhatian dari enam agama formal di indonesia, seperti gerakan aliran Here Krisna ini merupakan gerakan keagamaan yang bernaung di bawah agma Hindu akan tetapi peraktek beribadatannya tidak seperti agama hindu pada umumnya.

\section{METODE PENELITIAN}

Dalam penulisan aetikel ini, penelitian ini menggunakan pendekatan kualitatif, dalam bentuk studi kasus, dengan menggali data-data melalui informan dengan metode wawancara, observasi, serta studi pustaka. Dalam menunjang penulisan ini penulis menambahkan data-data sekunder berupa norma dasar peraturan per Undangundangan yang memiliki kaitannya dengan tulisan ini. Dari hasil penelitian ini diharapkan dapat memberikan wawasan baru terhadap aliran keagamaan baru yang ingin tumbuh dan berkembang di Indonesia.

\section{EKSISTENSI HERE KRISNA}

1. Sejarah berdiri dan Berkembangnya Ashram Here Krisna

Hare Krisna atau yang biasa disebut dengan Ashram Hare Krisna adalah sebuah lembaga keagamaan yang bergerak di bidang pendidikan Agama Hindu non formal. Pengambilan kata "Hare Krisna" diambil dari bahasa sanskerta, yaitu Hare berarti Sakti (kata

8 Budiyono, "Hubungan Negara dan Agama Dalam Negara Pancasila", Jurnal Ilmu Hukum 8, no. 3, (2014): 410 
dari Krisna), Krisna artinya Tuhan dan Ashram berarti dari sebuah pemondokan atau tempat tinggal. Sistem lembaga tersebut hingga kini masih tahap pengembangan oleh para pendiri dan pengurus serta Brahmacari yang telah menmpuh pendidikan di Hare Krisna.

Kelompok spiritual Here Krisna dikenal luas sebagai kelompok yang mengajarkan mantra zikir "Here Krisna, Here Krisna, Krisna-krisna, Herehere, Here Rama, Here Rama, Rama-rama, Here-here". Mantra ini berasal dari kitab Kalisantara Upanisad, yang merupakan salah satu bagian dari kitab-kitab Veda (Yajur Veda). Ajaran kelompok spiritual Here Krisna tersebar luas keseluruh dunia atas jasa dari Srila Prabhupaba yang pada tahun 1965 meninggalkan India menuju Amerika Srikat untuk menyampaikan ajaran ini kedunia Barat, dan pada saat itu ajaran ini langsung memikat banyak pemuda di Amerika yang frustasi dengan kemampuan metrealismenya. ${ }^{9}$

Pada tahun 1973 Srila Prabhupada mengunjungi Jakarta dan membuka pengajaran ini. Selama tahun 1980-an ada dua pusat pengajaran di Indonesia, pertama bertempat di Jakarta (Rawamangun) dan di Bali (Sagamona). Pada tahun 2002 tepatnya tanggal 1 Jaanuari, didirikan Sakkhi (Sampradaya Kesadaran Krisna Indonesia) untuk bertindak sebagai perantara antara pihak anggota perkumpulan yang jumlahnya semakin bertambah dengan Dewan Hindu Dharma di Indonesia (Parisada Hindu Dharma Indonesia). ${ }^{10}$

Hare Krisna adalah kelompok atau komunitas spritual yang memberikan pemahaman terhadap Krisna, karena merupakan pemahaman terhadap Krisna maka tidak dapat digolongkan atau dikelompokkan dalam agama akan tetapi tidak diluar agama, karena kesadaran terhadap Tuhan Yang Maha Kuasa (Krisna) dapat dilakukan dimana saja. Hare Krisna meyakini jika

9 Suhanah, "Kelompok Spritual Sakkhi dan Dampak Terhadap Kehidupan Keagamaan di Indonesia", Jurnal Multikultural dan Multireligius 15, no. 3 (2016): 120.

10 Suhanah, "Kelompok Spritual Sakkhi dan Dampak Terhadap Kehidupan Keagamaan di Indonesia", 121. dikelompokkan terhadap agama maka akan memicu perbedaan dan tidak mempunyai tujuan yang sama yaitu Tuhan.

Di Indonesia khususnya di wilayah Daerah Istimewa Yogyakarta membentuk juga suatu lembaga Pendidikan Agama non formal yang bergerak melalui bidang pendidikan yang disebut dengan nama Asrham Here Krisna. Lembaga tersebut berbentuk Yayasan Pendidikan tepatnya didirikan pada 11 September 1991 dan mendapatkan legalitas Pengadilan Negeri Sleman Yogyakarta dengan Nomor W22 Dd. Hr 04. 01. 53.

Adapun hal-hal yang menunjang terbentuknya lembaga ini adalah adanya perasaan prihatin terhadap fenomena, dimana kalangan umat Hindu khususnya generasi muda masih banyak yang belum mendapatkan atau mengetahui tentang pelajaran yang mendalam tentang ajaran Hindu itu sendiri secara jelas, yaitu mengenai dasar-dasar pemikiran (Filosofi) karena umat Hindu pada umumnya masih terikat dengan istilah Guyon Tuwon (Tradisi Turun Temurun) tanpa mengetahui makna filosofisnya. ${ }^{11}$ Sehingga yang tidak disadari sesuatu yang diajarkan secara turun temurun tanpa didasari pengetahuan yang jelas akan memberikan pemahaman yang salah, dan apabila tidak segera ditanggulangi barang tentu kesalahan akan pemahaman agama akan terus berlanjut.

Dari fenomena itu maka Bapak Budi Raharjo merasa prihatin dan berinisiatif untuk membentuk yayasan Asrham Here Krisna sebagai tempat belajar yang bersifat nonformal sebagai langkah untuk menanggulangi kekeliruan atas pemahaman yang diajarkan secara turun temurun, dan berusaha untuk mengembalikan entitas kemurnian akan pemahaman agama Hindu.

\section{Pokok Ajaran Here Krisna}

Agama Hindu merupakan agama yang mengajarkan tentang banyak hal, baik ilmu yang berhubungan dengan dunia materi maupun dunia

11 Budi Raharja, (Pengasuh Ashram Hare Krisna Yogyakarta), di Sleman Yogyakarta, Wawancara tanggal 18 April 2019. 
rohani. Bagi masyarakat Hindu, agama hindu dikenal dengan nama Sanata Dharma (kebenaran yang abadi) namun kebanyakan masyarakat menyebutnya sebagai Hindu karena agama ini lahir dari lembah sungai Shindu. Selain mengajarkan banyak hal agama Hindu juga memiliki banyak kitab suci, baik sruti maupun smriti yang juga memiliki beberapa aliran seperti shaivisme, vaishnavisme, dan srauta.

Meskipun agama Hindu menajarkan tentang banyak hal tetapi dari keseluruhan ajarannya memiliki inti atau pokok ajaran yang dikonsepkan kedalam tiga kerangka dasar yakni filsafat (tattwa), etika (susila), dan upacara (yadnya). Selain itu agma Hindu juga mengarkan tentang Panca Sradha (lima dasar keyakinan umat Hindu) yang melitputi Widhi Tattwa (keyakinan terhadap Tuhan Brahman), Atma Tattwa (keyakinan terhadap Atman Roh), Karmaphala Tattwa (keyakinan pada karmaphala atau hukum sebabakibat), Punarbawa Tattwa (keyakinan pada kelahiran kembali atau reinkarnasi), dan Moksa Tattwa (keyakinan akan bersatunya Atman dengan Brahman). ${ }^{12}$ Secara umum ajaran agama hindu termuat dalam kitab sucinya yang dikenal dengan kitab Weda.

Sedangkan aliran Here Krisna memiliki kitab suci yang menjadi sumber ajarannya adalah kitab Bhagavad Gita dan kitab Purana. Namun yang membedakan antara agama Hindu dan aliran Here Krisna adalah prakteknya dalam mempercayai Trimurti tidak secara khusus melainkan hanya secara umum. Kerena menurut pengikut Here Krisna Trimurti adalah perwujudan dari tuhan Krisna. ${ }^{13}$

Para pengikut ajaran Here Krisna memiliki satu tujuan hidup yaitu mengembalikan kesadaran dan keyakinan semua orang kepada tuhan Krisna sebagai entitas tertinggi, bahkan lebih tinggi dari

12 I Kett Mertamupu, “Ajaran Agama Hindu",https://www.kompasiana.com/mertamupu/55176 548a33311b906b6603b/inti-ajaran-hindu diakses tanggal 2 Mei 2019

13 Suhanah, "Kelompok Spritual Sakkhi dan Dampak Terhadap Kehidupan Keagamaan di Indonesia", Jurnal Multikultural dan Multireligius 15, no. 3 (2016): 125.
Tri Murti. Dalam ajaran ini dapat dipahami bahwasanya posisi Tuhan Krisna dalam konsep teologis ajaran Here Krisna sangat supremasi melampaui posisi Sang Hyang Widi Wase yang oleh pemeluk agama Hindu pada umumnya disebut sebagai entitas tertinggi. Kedudukan Tri Murti yakni Syiwa, Brahma dan Whisnu dalam ajaran Here Krisna merupakan dewa-dewa yang diperintahkan Tuhan Krisna untuk mengatur alam semesta sesuai dengan tugas dan kedudukannya masing-masing.

Sri Krisna juga diyakini sebagai perwujudan keabadian, pengetahuan, dan kebahagiaan. Sri Krisna diyakini sebagai personalitas tertinggi Tuhan yang Maha Esa, yang mengendalikan segala ciptaannya sebagai jelma an Tuhan yang tidak memiliki asal muasal atau sumber, melainkan sumber segalanya dan sebab dari segala sesuatu dan merupakan kebenaran mutlak tertinggi dan perwujudan kebahagiaan abadi. ${ }^{14}$

Dalam ajaran Here Krisna juga menurut Budi Raharja terdapat empat prinsip etika atau moralitas yang harus dijalani oleh pengikutnya yaitu, tidak boleh memakan daging, ikan, dan telur, mabuk-mabukan, berjudi, dan berjina. Prinsip ini merupakan prinsip untuk bagaimana kita menghargai kehidupan. Selain prinsip-prinsip tadi ada juga pilar kebaikan yakni kebenaran (dharma), kejujuran (satya), kasih sayng (prema), kedamaian (shanti), dan tidak saling menyakiti (ahimsa). Untuk memperkokoh prinsip tersebut dan ingin memusatkan pikiran untuk mencapai indra dalam pencapaian spiritual, para pengikut ajaran Here Krisna harus mengikuti aturan dasar berupa diet vegetarian, dan tidak melakukan larangan-larangan seperti disebutkan tadi. ${ }^{15}$

Dalam ajaran Here Krisna meyakini bahwa sumber daya alam, lingkungan, dan tubuh manusia adalah pemberian suci Tuhan dan harus

14 Suhanah, "Kelompok Spritual Sakkhi dan Dampak Terhadap Kehidupan Keagamaan di Indonesia", 123-124.

15 Budi Raharja, (Pengasuh Ashram Hare Krisna Yogyakarta), di Sleman Yogyakarta, Wawancara tanggal 18 April 2019. 
dikelola dengan penuh tanggungjawab. Filososfi dalam ajaran Here Krisna bahwa setiap makhluk hidup saling memiliki jalinan hubungan dengan Krisna sebagai Tuhan yang tertinggi.

Aliran Here Krisna tentunya selalu memberikan penghormatan tentang hak hidup kepada makhluk hidup khususnya hak hidup binatang, dan menjalani pola hidup seminimal mungkin untuk meminimalisir untuk melakukan kekerasan serta eksploitasi. Oleh karenanya, kelompok aliran Here Krisna memandang bahwa vegetarian akan memberikan keuntungan ekologi, sosial, keselarasan hidup, dan kesehatan merupakan pola hidup yang cocok untuk mengembangkan cinta kasih antar sesama makhluk hidup.

\section{POLITIK KEAGAMAAN}

Di Indonesia pada umumnya setelah kemerdekaan, persoalan agama dan kepercayaan menjadi suatu masalah yang serius. Kata "kepercayaan" yang dimaksut menunjuk pada ajaran pandangan hidup berkepercayaan kepada Tuhan Yang Maha Esa yang tidak bersandar sepenuhnya kepada ajaran agama-agama yang diakui oleh pemerintah Indonesia. Pada saat pecahnya peristiwa G30S tahun 1965 agama dan kepercayaan mengalami benturan dimana tuduhan komunis bagi penganut kepercayaan sehingga menimbulkan eksodus (meninggalkan) besarbesaran ke agama-agama yang di akui pemerintah. ${ }^{16}$

Setiap pemeluk agama pasti meyakini aspek ajaran yang dianggap suci oleh penganutnya, yang dengannya nilai-nilai keagamaan senantiasa diaktualisasikan dalam kehidupan sehari-hari. Dari keyakinan itu kemudain agama dijadikan sebagai acuan normatif dalam kehidupan sehari-hari baik oleh individu maupun kelompok. Pada saat yang sama juga dapat kita pahami bahwasanya latar belakang yang

16 Aryono, "Pergulatan Aliran Kepercayaan Dalam Panggung Politik Indonesia, 1950an-2010an: Romo Semono Sastrodihardjo Dan Aliran Kapribaden", Jurnal Sejarah Citra Lekha 3, no. 1 (2018): 60. berbeda baik dari pendidikan, pemikiran, persepsi, interprestasi, dan ekspresi keberagaman merupakan awal dari munculnya individu-individu yang memiliki kecenderungan pemikiran dan pengalaman ${ }^{17}$ terhadap ajaran yang di anggap benar sebagai sesuatu hal yang mutlak. Dari pemahaman itu ada individu yang memiliki kecenderungan dalam kesamaan pemikiran, dan pada wilayah tertentu ada pula pemahaman yang berbeda.

Pada dasarnya setiap gerakan keagamaan yang terorganisir menyebabkan suatu paham dan interprestasi terhadap suatu agama yang sudah ada bisa disebut sebagai sekte atau sempalan. Dalam memahami ajaran sempalan yang lahir dari agama yang sudah berkembang sejak lama, kita dapat mencermati karakteristik yang ada yaitu dengan adanya doktrin teologi yang berbeda dengan agama sebelumnya, secara khas dipahami oleh kelompoknya, dan kemudian melahirkan monopoli kebenaran.

Keberadaan agama sempalan ini bisa dikategorikan sebagai suatu sistem yang menyimpang dari ajaran induknya. Dari ajaran itu lahirlah kecenderungan klaim atas kebenaran oleh penggagas dan pengikutnya, salah satu ciri yang paling Nampak yaitu adanya pola peribadatan yang berbeda dari ajaran induknya, dengan didasarkan pada sikap penolakan terhadap otoritas individu atau otoritas institusi terhadap interprestasi ajaran agama. ${ }^{18}$

Setiap pemeluk agama didunia termasuk didalamnya masyarakat pemeluk aliran yang berbeda dari ajaran induknya, meyakii bahwa fungsi dari pada agama adalah memandu kehidupan manusia agar memperoleh keselamatan di dunia maupun keselamatan di akhirat. Setiap agama maupun aliran yang diyakini selalu mengajarkan nilai kasih sayang pada kepada

17 Abbas Langaji, "Dinamika Aliran Keagamaan Sempalan: Tinjauan Perspektif Sosiologi Agama", Jurnal Hikmah XII, no. 1 (2016): 145.

18 Abbas Langaji, "Dinamika Aliran Keagamaan Sempalan: Tinjauan Perspektif Sosiologi Agama”, 146-147. 
sesama sebagai tanggung jawab sebagai makhluk ciptaan Tuhan.

Dalam perbincangan tentang agama atau aliran kepercayaan, baik secara teologis maupun sosiologis, agama dapat dipandang sebagai instrument untuk memahami dunia. Secara sosiologis tak jarang agama atau aliran kepercayaan menjadi factor penentu dalam proses transformasi dan modernisasi dalam mengikuti perkembangan jaman. Sementara secara teologis tersebut dikarenakan oleh watak omnipresent agama, yaitu agama baik melalui simbol-simbol atau nlai-nilai yang dikandungnya dapat hadir dimana-mana, serta ikut mengatur tatanan sosial, budaya, akonimi, politik dan kebijakan publik. Dengan ciri-ciri ini tentunya agama maupun aliran keagamaan dapat memberikan panduan nilai sebagai seluruh diskursus manusia baik sosial, budaya politik, maupun ekonomi. ${ }^{19}$

Kebebasan beragama dan memeluk keyakin tentunya merupakan Hak dari individu itu sendiri. Dikarenakan agama merupakan nilai moralitas yang bersifat vertical antar manusia dengan tuhan yang dapat ditempuh dengan jalannya sendiri, bukan dengan jalan keyakian orang lain, terlebih menghakimi orang lain dengan kebenaran yang dianut oleh kelompok tertentu.

Moralitas keyakinan seseorang terhadap agama atau aliran kepercayaan yang bersifat horizontal, tentunya harus diberikan kebebasan selama itu tidak memberikan dampak negatif dalam konteks hubungan sosial dan hubungan bernegara. Karna kebenaran itu sifatnya objektif, dan manusia hidup memiliki tujuan utama yakni ingin menggambarkan wujud Tuhan dengan tingkah laku sosialnya

Dengan adanya perbedaan pandangan serta nilai yang ingin dituju tentunya akan adanya konflik yang terjadi, karena konflik merupaka gejala yang umum yang sering terjadi di masyarakat, kelompok, dan individu. ${ }^{20}$ Ketika

19 Kiki Muhamad Hakiki, "Politik Identitas Agama Lokal”, Jurnal Analisis XI, no. 1 (Juni, 2011): 160-161.

20 Ulfah Fajarini, "Potret Konflik Keagamaan Masyarakat Tangerang Banten Dan Resolusi Konflik dalam suatu agama memiliki banyak aliran kepercayaan yang berkembang, tidak menutup kemungkinan akan terjadinya koflik atau pertentangan yang bersifat individu atau kelompok. Dalam tulisan ini konflik yang dimaksut adalah konflik yang bersifat internal dalam suatu lembaga keagamaan yang didalamnya memiliki berbagai macam aliran keyakinan yang berbeda dari agama sebenarnya, dimana setiap aliran yang berkembang ini ingin memperlihatkan identitas golongannya yang kemudian dapat diakui eksistensinya.

Relasi sosial pengikut Here Krisna dengan umat Hindu pada umumnya berlangsung dengan baik dan harmonis. Sejauh ini dengan perbedaan pendapat dalam cara meyakini Tuhan dan cara beribadah yang berbeda tidak menjadi masalah, umat Hindu pada umumnya dan umat aliran Here Krisna bisa hidup berdampingan dan saling menghormati. Kemunculan aliran Here Krina tidak menjadi maslah bagi pihak PHDI, karena keberadaannya tidak membuat resah terhadap umat Hindu pada umumnya. Karena umat Hidu dan Umat aliran Here Krisna berpemahaman terhadap sloka Bhagavad Gita yang berbunyi "Bagaimanapun jalan manusia mengikuti-Ku. Aku terima, wahai arjuna, manusia mengikuti pada segala jalan". ${ }^{21}$ Ini merupakan pedoman yang mereka yakini sebagai toleransi untuk tetap menjaga keharmonisan antar sesama.

Berkaitan dengn relasi Ashram Here Krisna dan ketua PHDI Provinsi Yogyakarta menyarankan untuk mereka agar saling berbaur, tidak eksklusif dan ritual yang sudah ada di tempat persembahyangan mereka tidak dibawa ketempat ke pura. Penganut aliran Here Krisna boleh menggunakan Sri Krisna, sebab dalam dasar agama Hindu terdapat tiga hal yang harus dipahami yaitu, agamanya sama-sama Hindu, mengakui kitab yang sama yaitu weda, dan

Berbasis Multikulturalisme Dalam Islam", Jurnal Al-Tahrir 14, no. 2 (Mei, 2014): 349.

21 Budi Raharja, (Pengasuh Ashram Hare Krisna Yogyakarta), di Sleman Yogyakarta, Wawancara tanggal 18 April 2019 
etikanya juga sama yang membedakan hanya ritual peribadatannya. ${ }^{22}$

Sebagian besar umat Hindu pada umumnya mengakui ajaran Here Krisna, karena kelompok ini masih mengakui sebagai penganut agama Hindu dan mengakui kitab Weda sebagai kitab suci. Disisi lain PHDI itu sendiri mengayomi keberadaan aliran Here Krisna sepanjang mereka bisa hidup berdampingan, tidak bersikap ekslusif, meskipun masalah teologi dan ritualnya berbeda.

Perbedaan yang terjadi dalam meyakini Tuhan-Nya dan dengan ritual yang berbeda tidak menjadi suatu masalah selama didalam perbedaan itu tidak membawa dampak negatif, karena beragama bukan suatu paksaan yang memaksa kita untuk bersiakp eksklusif, melainkan dengan adanya perbedaan ini harus dibuka ruang interaktif untuk bisa saling menerima satu sama lain dalam mengakui keberadaan Tuhan dan cara menyembah (ibadah), walaupun perbedaan itu lahir dari satu rahin agama yang sama.

\section{RELASI AGAMA DAN NEGARA}

Kebebasan beragama merupakan hak bagi setiap masyarakat untuk meyakini ajaran yang dianutnya. Seperti yang tertulis pada Undangndang No. 1/PNPS/1965 yang pada dasarnya bertujuan melindungi kehormatan agama. Hal agama dan beragama merupakan hak asasi yang dimiliki manusia sebagaimana ditegaskan dalam Pasal 18 Deklarasi Umum Hak Asasi Manusia yang menyatakan Hak asasi bagi tiap manusia sebagai individu untuk beragama dan beribadah sesuai dengan agamanya tanpa pengekangan. ${ }^{23}$

Indonesia merupakan negara yang memiliki falsafah dengan menerima Pancasila sebagai dasar negara. Dalam konsekuensi diterima dan diakuinya Pancasila sebagai dasar negar tentunya harus dipahami kaidah-kaidah

22 Budi Raharja, (Pengasuh Ashram Hare Krisna Yogyakarta), di Sleman Yogyakarta, Wawancara tanggal 18 April 2019.

23 Hwian Christianto, "Arti Penting Uu No. 1/Pnps/1965 Bagi Kebebasan Beragama”, Jurnal Yudisial 6, no. 1 (April, 2013): 9-10. penuntun bagi pembuatan kebijakan dalam hokum nasional. Dari Pancasila ini lahirlah empat kaidah penuntun dalam pembuatan politik atau kebijakn suatu negara. Yang pertama kebijakn harus menjaga integrasi atau keutuhan bangsa baik secara ideologi maupun secara teritori, artinya kebijakan yang dikelurkan tidak boleh menyebabkan atau berpotensi mengancam keutuhan bangsa baik ideologis maupun wilayah teritorisnya. Kedua, kebijakan harus didasarkan pada upaya untuk membangun demokrasi (kedaulatan rakyat) dan nomokrasi (negara hukum), yang berarti menyerahkan pemerintahan dan penentuan arah kebijakn pada rakyat melalui kontestasi politik sehat. Ketiga, kebijakn umum harus disandarkan dalam upaya membangun keadilan sosial bagi seluruh rakyat Indonesia. Keempat, kebijakn umum dan politik harus didasarkan pada prinsip toleransi beragama yang berkeadaban. ${ }^{24}$

Kehidupan beragama di Indonesia secara yuridis mempunyal landasan yang kuat sebagaimana ternmaktub dalam Undang-undang Dasar 1945. Negara berdasarkan Ketuhanan Yang Maha Esa, mengandung prinsip bahwa bangsa Indonesia adalah bangsa yang beragama, dan bukan bangsa yang berlandaskan agama tertentu, dan bukan pula suatu negara yang sekuler yang memisahkan agama dengan urusan negara.

Berdasarkan pasal 29 Undang-undang Dasar 1945, pemerintah berkewajiban mengatur kehidupan beragama di Indonesia. Sebagai pelaksana pasal 29 ayat (2) Undang-undang Dasar 1945 pemerintah mengelurkan Undang-undang No. 1/PNPS/1965 tentang pencegahan dan penyalahgunaan dan/atau penolakan agama yang dikukuhkan oleh Undang-undang No.5 Tahun tentang pernyataa berbagai penetapan Presiden dan peraturan Presiden sebagai Undang-undang. Salah satu bentuk keikutsertaan pemerintah dalam persoalan agama adalah dengan adanya pengakuan terhadap beberapa agama di Indonesia.

24 Budiyono, "Hubungan Negara dan Agama Dalam Negara Pancasila", Jurnal Ilmu Hukum 8, no. 3 (2014): 414-415. 
Pengakuan ini muncul dalam bentuk surat edaran Mentri Dalam Negri No. 477/74054/1978 yang menyebutkan antara lain agama yang diakui oleh pemrintah adalah Islam, Katolik, Kristen/Protestan, Hindu, Budha, dan Khong Hu $\mathrm{Cu}^{25}$ Pengakuan akan enam agama tentunya menutup ruang bagi aliran atau agama lain untuk berkembang di Indonesia. Maka dari itu ketika ada aliran kepercayaan lain yang berkembang tentunya harus masuk dalam agama yang direstui oleh pemerintah itu sendiri, dan ideologi yang diajarkan tidak boleh bertentangan dengan ideologi bangsa Indonesia.

\section{Hubungan Agama dengan Negara}

Memahami hubungan antara agama dan negara yang paling dasar harus mengetahui ideologi yang di anut oleh suatu negara. Indonesia yang menganut Pancasila sebagai ideolgi dan pandangan hidup berpangkal pada satu keyakinan bahwa alam semesta dan seluruh isinya merupakan kesatuan yang harmonis adalah hasil ciptaan Tuhan. Manusia termasuk dalam makhluk ciptaan tuhan yang memiliki kewajiban untuk bermasyarakat, dan memenuhi kebutuhan hidupnya. Dalam kebersamaan yang ada manusia dikodratkan berbeda antara satu dengan lainnya. Keselurusan kesatuan yang berbeda itu mewujutkan satu kesatuan yang tergambar pada lambing negara Republik Indonesia. Kodrat perbedaan itu dirumuskan dalam semboyan Bhineka Tunggal Ika, yang sampai hari ini menjadi semboyan bangsa Indonesia bagi masyarakatnya bertujuan untuk tetap mempertahankan eksistensinya sebagai masyarakat untuk saling mengakui dan menghargai perbedaan yang ada di masyarakat. ${ }^{26}$

Indonesia sebagai negara yang berdasarkan atas Ketuhanan Yang Maha Esa sekaligus negara hukum harus memandang sebagai satu kesatuan yang saling mendukung

25 Budiyono, "Hubungan Negara dan Agama Dalam Negara Pancasila", Jurnal Ilmu Hukum 8, no. 3 (2014): 410-411.

26 Budiyono, "Hubungan Negara dan Agama Dalam Negara Pancasila", 415. antara satu dengan yang lainnya. Konsepsi negara hukum membawa konsekuensi bagi Indonesia untuk mengatur segala tatanan kehidupan masyarakat dengan hukum demi terciptanya ketertiban dan kepastian hukum. ${ }^{27}$

Relasi antara agama dan negara pada prinspnya adalah agama sebagai control sosial yang berkaitan dengan norma dan etika, sedangkan hukum atau aturan sebagai pengayom bagi masyarakat agar mendapatkan kedamaian dan keadilan. Maka dari itu negara yang berasas pada Ketuhanan yang Maha Esa, kehidupan agama tidak boleh dipisahkan dari negara melainkan agama harus mendapat legitimasi filosofis, yuridis, sosiologis, dan politis dalam negara, sebagaia mana yang tercantum dalam Undang-undang Dasar 1945.

Secara filosofis sila pertama Ketuhanan Yang Maha Esa berkedudukan sebagai dasar filosofis bagi kehidupan berbangsa dan bernegaa dalam hal hubungan agama dengan negara. Dari landasan ini dapat dipahami bahwasanya setiap warga negara bebas berkeyakian atau memeluk agama sesuai dengan keyakinan dan kepercayaannya. Kebebasan dalam pengertian ini bahwa keputusan beragama dan beribadah diletakkan pada domain privat atau individu itu sendiri. Negara dalam hal ini cukup menjami secara yuridis dan memfasilitasi agar warga negara dapat menjalankan agama dan peribadahan dengan rasa aman, tentram, dan damai. ${ }^{28}$

Pengakuan akan eksistensi agama dalam kehidupan bernegara diwujutkan dalam bentuk lemaga-lembaga keagamaan dalam negara serta adopsi nilai dan norma dari agama dalam sistem nasional. Keyakinan beragama secara sosiologis dan politis harus diletakkan pada kedudukannya sebagai agama yang diakui oleh pemerintah dan ajarannya tidak menentang ideologi bangsa sebagai dasar negara. Ketika ada ajaran yang

27 Hwian Christianto, "Arti Penting Uu No. 1/Pnps/1965 Bagi Kebebasan Beragama”, Jurnal Yudisial 6, no. 1 (April, 2013): 4.

28 Budiyono, "Hubungan Negara dan Agama Dalam Negara Pancasila Jurnal Ilmu Hukum 8, no. 3 (2014): 416-417. 
disampaikn bertentangan dengan agama induknya dan ideologi bangsa tentu ada upaya dari pemerintah dalam menanggulangi ajaran tersebut.

Dalam kehidupan bersama ini tentunya negara maupun semua aliran dan paham agama boleh dibenarkan selama ajarannya tidak bertentangan dengan ideologi bangsa. Negara dalam konteks ini tentunya cukup menjamin secara yuridis dan memfasilitasi agar warga nega ra dapat menjalankan agama dan beribadah dengan rasa nyaman. Apabila dalam hal ini kepercayaan warga negara dalam beragama terindikasi menyimpang dari idielogi bangsa, negara memiliki legitimasi yang diwujutkan dalam bentuk lembaga yang memiliki wewenang untuk bertugas mengelurkan pedoman dan mengidentifikasi aliran itu termasuk aliran yang menyimpang atau bukan.

\section{Hubungan Agama, Masyarakat, dan Budaya}

Manusia sebagai makhluk berakal dan beragama tetap memiliki kebebasan berkehendak untuk menyatakan pikiran, ide, dan menentukan jalan hidupnya. Indonesia merupakan salah satu Negara yang mempunyai kekayaan berlimpah dan terdiri atas beberapa kepulauan yang mempunyai beranekaragam budaya, suku-bangsa, dan agama, ${ }^{29}$ ini merupakan kekayaan yang dimiliki bangsa Indonesia.

Sejak awal perkembangannya agamaagama di Indonesia telah menerima akomodasi budaya. Agama tentunya banyak memberikan norma-norma atau aturan tentang kehidupan, paling tidak ada dua hal yang harus dipahami yaitu, agama sebagai konsepsi sosial budaya dan agama sebagai realitas budaya. ${ }^{30}$ Karena pada dasarnya perkembangan serta reaktualisasi ajaran agama adalah untuk bisa menjawab berbagai

29 Rofiqoh Zuchairiyah, "Kekerasan Terhadap Pengikut Aliran Yang Dinilai Sesat Dalam Perspektif Hukum Islam”, Jurnal Agama Dan Hak Azazi Manusia 1, no. 2 (Mei, 2012): 369-370.

30 Laode Monto Bauto, "Perspektif Agama Dan Kebudayaan Dalam Kehidupan Masyarakat Indonesia", Jurnal Pendidikan Ilmu Sosia 23, no. 2 (Desember, 2014), 14. macam pertanyaan problematika jaman yang hari ini semakin kompleks.

Kompleksitas pemahaman keagamaan dan kebudayaan yang berkembang dimasyarakat dapat kita pahami sebagai ekspresi kehidupan masyarakat dalam menjalin hubungan dirinya, agama dan budaya yang dianutnya. Dalam tradisi hubungan masyarakat dengan agama dapat dipahami sebagai doktrin yang sifatnya permanen atau merupakan interprestasi yang melekat ketat pada ajaran dasarnya atau secara umum kita memahami sebagai konsepsi keimanan yang menjadi inspirasi dalam berfikir dan bertindak. Begitu juga relasi antara masyarakat dan budaya merupakan tradisi kecil yang berkembang dibawah pengaruh agama itu sendiri. Pengaruh tersebut mencakup unsur-unsur yang terkandung didalam pengertian budaya yang meliputi konsep atau norma, aktivitas tindakan manusia berupa karyakarya yang dihasilkan oleh masyarakat. ${ }^{31}$

Memahami perkembangan serta korelasi diantara masyarakat, agama dan budaya secara fisik kita dapat mengakulturasi budaya dalam ajaran keagamaan, selama itu tidak bertentangan dengan nilai keagamaan yang bersifat doctrinal, melainkan akultarasi ini dapat dikembangkan pada nilai keagamaan yang bersifat pengembangan kreaktifitas sosial dan kemasyarakatan.

Negara yang berdasarkan Pancasila dan UUD 1945, dimana Ketuhanan Yang Maha Esa bukanlah negara yang terpisah dari agama, tapi juga tidak menyatu dngan agama. Hubungan ideal antara negara dan agama harus memiliki prinsip yang secara aktif dan dinamis untuk membimbing, menyokong, memelihara, dan mengembangkan agama dan kepercayaan. Dapat juga diartikan bahwasanya selama kegiatan keagamaan yang dilakukan tidak bertentangan dengan dasar negara, agama menjadi persoalan individu bukan persoalan negara.

Negara dalam hubungan ini sangat menjamin rasa aman, tenteram, dan damai tanpa

31 Laode Monto Bauto, "Perspektif Agama Dan Kebudayaan Dalam Kehidupan Masyarakat Indonesia”, 14. 
tanpa ada gangguan dari setiap orang lain ataupun kelompok masyarakat, selama keyakinan itu tidak menimbulkan gangguan ketertiban dan keteraturan masyarakat, karena pada prinsipnya agama dan negara adalah salig membutuhkan. Agama membutuhkan negara sebagai pengayom dan perkembangan agama, dan negara membutuhkan agama untuk meningkatkan moral bangsa itu sendiri.

\section{KESIMPULAN}

Dari uraian penjelasan di atas dapat dipahami bahwasanya ajaran Here Krisna itu tidak dipertentangkan didalam ajaran agama Hindu walaupun pengakuan atas Tuhan dan pola peribadatannya berbeda. Karena ajaran Here Krisna menganggap Tuhan Krisna lebih tinggi drajatnya, bahkan lebih tinggi dari Trimurti. Pokok ajarannya diambil dari kitab Bhagavad Gita dan kitab Purana. Pola beribadahnya juga berbeda dengan agama Hindu pada umumnya, aliran Here Krisna beribadah dengan pola sembayang di depan altar yang di situ tersedia dupa, lilin dan foto Tuhan Krisna.

Aliran Here Krisna merupakan aliran kepercayaan yang bernaung pada Agama Hindu. Tetapi internal dalam agama Hindu itu sendiri tidak mempermasalahkannya karena umat Hidu dan Umat aliran Here Krisna berpemahaman terhadap sloka Bhagavad Gita yang berbunyi "Bagaimanapun jalan manusia mengikuti-Ku. Aku terima, wahai arjuna, manusia mengikuti pada segala jalan". Artinya jalan menyembah Tuhan walaupun dengan cara beribadah berbeda mereka tetap diterima oleh Tuhan-Nya.

Begitu juga pengakuaanya di negara ini, secara legalitas formal aliran Here Krisna diakui sebagai agama Hindu, karena pada prinsipnya yang diakui oleh negara ini hanya ada enam agama besar. Ideologi yang diajarkan juga tidak bertentangan dengan ideologi Pancasila, karena aliran ini hanya mengajarkan tentang ketenangan jiwa dengan melatih mental serta spiritual para pengikutnya.
Aliran apapun yang akan berkembang di Indonesia tetap harus diayomi oleh pemerintah, karena pada dasarnya pemerintah adalah pengayom bagi masyarakat dan harus memberikan rasa aman, damai dan ketentraman. Selama ajaran itu tidak mengancam kesatuan bangsa, tidak bertentangan dengan Pancasila sebagai falsafah bangsa dan aliran kepercayaan itu bernaung dibawah agama resmi, mereka tetap memiliki hak penuh untuk mendapatkan keadilan dalam hal meyakini dan mengajarkan kepercayaannya.

\section{DAFTAR PUSTAKA}

Aryono. "Pergulatan Aliran Kepercayaan Dalam Panggung Politik Indonesia, 1950an2010an: Romo Semono Sastrodihardjo Dan Aliran Kapribaden", Jurnal Sejarah Citra Lekha 3, no. 1 (2018): 60.

Bauto, Laode Monto. "Perspektif Agama Dan Kebudayaan Dalam Kehidupan Masyarakat Indonesia", Jurnal Pendidikan Ilmu Sosia 23, no. 2 (Desember, 2014), 14.

Budiyono. "Hubungan Negara dan Agama Dalam Negara Pancasila", Jurnal Ilmu Hukum 8, no. 3, (2014): 410-415.

Christianto, Hwian. "Arti Penting Uu No. 1/Pnps/1965 Bagi Kebebasan Beragama", Jurnal Yudisial 6, no. 1 (April, 2013): 9-10.

Fajarini, Ulfah. "Potret Konflik Keagamaan Masyarakat Tangerang Banten Dan Resolusi Konflik Berbasis Multikulturalisme Dalam Islam", Jurnal AlTabrir 14, no. 2 (Mei, 2014): 349.

Hakiki, Kiki Muhamad. "Politik Identitas Agama Lokal", Jurnal Analisis XI, no. 1 (Juni, 2011): 160-161.

Howell, Julia D. "Muslims, the New Age and Marginal Religions in Indonesia: Changing Meanings of Religious Pluralism", Jurnal Social Compas 52, no. 4 (2005): 474.

Kotimah. "Agama dan Civil Society", Jurnal Ushuluddin XXI, no. 1 (Januari 2014): 123.

Langaji, Abbas. "Dinamika Aliran Keagamaan Sempalan: Tinjauan Perspektif Sosiologi Agama", Jurnal Hikmah XII, no. 1 (2016): 141. 
Mertamupu, I Ketut. "Ajaran Agama Hindu",https://www.kompasiana.com/m ertamupu/55176548a33311b906b6603b/i nti-ajaran-hindu diakses tanggal 2 Mei 2019

Raharja, Budi. Pengasuh Ashram Hare Krisna Yogyakarta), di Sleman Yogyakarta, Wawancara tanggal 18 April 2019.

Suhanah. "Kelompok Spritual Sakkhi dan Dampak Terhadap Kehidupan Keagamaan di Indonesia", Jurnal Multikultural dan Multireligius 15, no. 3 (2016): 3 .

Takdir, Mohammad. "New Spiritual Movement: Menelisik Visi Transpormatif Komunitas Lia Eden sebagai Embrio lahirnya New Age di Indonesia", 3.

Zuchairiyah, Rofiqoh. "Kekerasan Terhadap Pengikut Aliran Yang Dinilai Sesat Dalam Perspektif Hukum Islam", Jurnal Agama Dan Hak Arazi Manusia 1, no. 2 (Mei, 2012): 369-370. 